\title{
Hands in the Cookie Jar: Exploiting Loan Loss Provisions under Bank Financial Distress
}

\author{
Malek El Diria ${ }^{\text {, Timothy King }}{ }^{\mathrm{b} *}$, Laima Spokeviciute ${ }^{c}$, Jonathan Williams ${ }^{\mathrm{d}}$ \\ aLeeds University Business School, University of Leeds, Leeds LS2 9JT, UK. \\ ${ }^{b}$ Kent Business School, University of Kent, Kent, CT2 7FS, UK \\ 'Cardiff University Business School, Cardiff University, Cardiff, CF10 3EU, UK \\ ${ }^{\mathrm{d} B a n g o r}$ Business School, Bangor University, Bangor, LL57 2DG, UK
}

\begin{abstract}
We investigate earnings management (EM) behaviour at failed banks by examining the intensity and direction of EM around FDIC-insured commercial bank failures. Our empirical analysis indicates that failing banks engage in EM to a significantly greater extent than nonfailing banks. Our results show that failing banks' discretion over loan loss provisions ranges from aggressive (upwards EM) to conservative (downwards EM).
\end{abstract}

Keywords: Earnings Management, Bank Failures, Banks JEL classification: G21; G33; M41

*Corresponding author: Timothy King

E-mail addresses: M.ElDiri@leeds.ac.uk (M. El Diri), t.p.king@kent.ac.uk (T. King), Spokeviciutel@cardiff.ac.uk (L. Spokeviciute), jon.williams@bangor.ac.uk (J. Williams). 


\section{Hands in the Cookie Jar: Exploiting Loan Loss Provisions under Bank Financial Distress}

\section{Introduction}

We investigate earnings management (EM) behaviour at failed banks. To the best of our knowledge, we are the first to examine EM in the context of bank failures. Bank failures are expensive to resolve and costlier than non-bank failures. ${ }^{1}$ Across 2008-2014, bank resolution costs were estimated to average 7\% of GDP in the OECD (Blix Grimaldi et al., 2016). Our interest is piqued because international accounting standards allow managers discretion to set accruals (Barth et al., 2017). Bank managers may use EM for strategic, opportunistic, or potentially unethical reasons; the line between ethical and unethical actions being a grey area that partitions legitimacy and fraud (Beatty et al., 2002).

Understanding the behaviour of failing banks is of special interest to bank regulators charged with ensuring financial stability. For regulators and prospective buyers of failed bank assets, identification of EM behaviour pre failure could signal unethical or possibly fraudulent practices by management (Kaplan and Ravenscroft, 2004). EM breeds concerns over the quality and reliability of financial reporting. Aggressive EM can induce greater risk-taking and higher incidence of corporate failures. EM, therefore, can challenge bank regulatory objectives: minimise systemic risk, safeguard safety-net arrangements, ensure banks are going concerns, and protecting customers.

Our analysis enhances understanding of EM in banking by contributing robust empirical evidence on the intensity and direction of EM around bank failures. We supplement research showing banks have used EM inter alia to smooth earnings and manage regulatory capital ("cookie jar reserves"), avoid losses, take bigger baths, signal private information about prospects, reduce tax liabilities, and increase executive pay (Ahmed et al., 1999; Beatty et al., 2002; Laeven and Majnoni, 2003; Cornett et al., 2009; Huizinga and Laeven, 2012; Beatty and Liao, 2014; Cohen et al., 2014; Norden and Stoian, 2014; Jiang et al., 2016; Barth et al., 2017; Dong and Zhang, 2018).

Loan loss provisions are the largest discretionary item in most banks' financial statements. While banks manage earnings by under-provisioning (income-increasing) or over-provisioning (income-decreasing), failing banks face different incentives when selecting their EM strategy. First, intensified agency conflict could motivate aggressive under-provisioning to boost retained earnings and regulatory capital (Beatty and Liao, 2011; Ng and Roychowdhury, 2014). In this scenario, upwardly manipulating income portrays banks as safer and healthier, enables refinancing of existing debt and/or raising new debt (Imperatore and Trombetta, 2014), and allows managers to extract rents and/or mask their intentions by delaying release of bad news that could expedite bankruptcy (Beatty et al., 2002; Bergstresser and Philippon, 2006; Beatty and Liao, 2011). This complies with conjecture that lower transparency is less costly as depositors have no incentive to run if there is no reason to believe the likelihood of

\footnotetext{
${ }^{1}$ James (1991) finds the realized costs of bank failures more expensive than non-banks by an amount equivalent to $10 \%$ of assets. Across 1986-2007, the FDIC estimated the cost to deposit insurance schemes of resolving depositinsured failed banks was roughly $\$ 30$ billion (Bennett and Unal, 2010).
} 
bank failure has increased, which reduces propensity to panic (Holmstrom, 2009; Calomiris and Gorton, 1991).

Second, failing banks may opt to over-provision and take bigger baths by reporting larger losses (Barth et al., 2017). This could reflect failing banks' awareness of increased regulatory surveillance to mitigate information asymmetries (Rosner, 2003). Holod and Peek (2007) find greater transparency allowed public banks to issue uninsured large time deposits and lessen financial constraints. Additionally, banks with smaller delays in provisioning find it easier to replenish equity which lessens stock market illiquidity risk as information asymmetries with equity providers decrease (Beatty and Liao, 2011).

The severity of 2007-09 GFC prompted heavy criticism of banks for alleged poor behaviour, misaligned incentives, and faulty business models (Brunnermeier, 2009; Schoen, 2017). Banks that chose aggressive EM pre-GFC experienced greater tail risk, larger write downs, and more failures during the crisis (Cohen et al., 2014). Banks were chastised for intentionally and unethically using complex financial instruments to obfuscate financial statements, making it harder for regulators, creditors, and stakeholders to accurately assess banks' financial condition (Wagner, 2007; Dewally and Shao, 2013). ${ }^{2}$ By increasing opacity, EM obscures the nature of banks' risk-taking (Bushman, 2014), which is concerning because bank risk-taking (and performance) has strong implications for the real economy.

Evidence from non-financial firms shows ex post bankrupt firms, which ex ante do not appear distressed, engage in significantly greater EM than non-distressed firms before bankruptcy. The EM behaviour of ex post bankrupts resembles firms the SEC sanctioned for fraud (Rosner, 2003). Deloitte's 2008 Forensic Centre Report reports that firms entering bankruptcy were "three times more likely than non-bankrupt companies to face enforcement actions by the SEC relating to alleged financial statement fraud". Barth et al. (2008) contend that managers of troubled firms perceive distress as a temporary situation to be concealed through EM until performance improves. Worryingly, aggressive EM behaviour shows little sign of abating.

\section{Methodology and Data}

Our novel setting allows us to contribute first evidence on the intensity and direction of EM around bank failures. We examine the EM behaviour of FDIC-insured commercial banks that failed (charter closed) or received regulatory assistance from the FDIC (charter survives). We construct our sample using Consolidated Reports of Condition and Income from the Federal Reserve Bank of Chicago (1984 to 1991) and FDIC (1992 to 2017). After omitting missing data, the sample comprises 257,881 bank-year observations from 16,894 unique banks. We identify 1,425 failed banks from the FDIC failed list; 1,326 were auctioned off to a succeeding charter and 99 received assistance.

\footnotetext{
${ }^{2}$ Criticisms prompted policy makers to prioritise reforms designed to improve the transparency of banks' financial reporting. Basel-3 guidelines implore greater transparency in banks' financial reporting and disclosure of banks' financial health to external investors. New international accounting rules like IFRS 9 address specific issues with methods used to set loan loss provisions.
} 
EM implies managers apply discretion when setting accruals. In banking, the two main accruals are loan loss provisions (LLP) and realised securities gains or losses. ${ }^{3}$ We focus on LLP as the larger accrual and most applicable to smaller banks. LLP is managers' present estimate of future losses from defaults on outstanding loans. ${ }^{4}$ Following Beatty et al. (2002), we estimate equation [1] to predict normal (expected) LLP with the residual measuring abnormal (unexpected) provisions:

$$
\begin{gathered}
L L P_{i, t}=\beta_{0}+\beta_{1} L L R_{i, t-1}+\beta_{2} N P L_{i, t-1}+\beta_{3} \Delta N P L_{i, t}+\beta_{4} C O_{i, t}+\beta_{5} \text { Loans }_{i, t} \\
+\beta_{6} \text { Loans }_{i, t}+\boldsymbol{\Pi} \boldsymbol{X}_{\boldsymbol{i}, \boldsymbol{t}}+\boldsymbol{Z} \boldsymbol{Y}_{\boldsymbol{t}}+\varepsilon_{i, t}
\end{gathered}
$$

Where for every bank $i$ at time $t(t-1), L L P$ is loan loss provisions; LLR is loan loss reserve; NPL is non-performing loans; $C O$ is net charge-offs; Loans is total loans and leases; $\Delta$ indicates change; $\boldsymbol{X}$ is a vector of loan types (real estate, commercial and industrial, consumer, agricultural); $\boldsymbol{Y}$ is a vector of year dummies. All variables, $\operatorname{bar} Y$, are expressed as ratios to total assets at $t-1$ and denominated in percentages.

To determine if failed banks manage earnings more or less aggressively than non-failed banks, we estimate equation [2] which specifies the absolute residuals from equation [1] as dependent variable and a binary variable, Fail, equals unity if a bank fails the following year, zero otherwise, alongside other covariates:

$$
\begin{aligned}
A L L P_{i, t} & =\gamma_{0}+\gamma_{1} F_{A I L_{i, t}}+\gamma_{2} \text { Loss }_{i, t}+\gamma_{3} L L P_{i, t-1}+\beta_{4} E B E L T_{i, t} \\
& +\beta_{5} \text { Capital }_{i, t-1}+\boldsymbol{K V}_{\boldsymbol{i t}}+\boldsymbol{Z Y}_{\boldsymbol{t}}+v_{i, t}
\end{aligned}
$$

Where for every bank $i$ at time $t(t-1), A L L P$ is abnormal LLP or abs $\left(\varepsilon_{i t}\right)$ from equation [1]; Loss equals unity if net income is negative, zero otherwise; $E B E L T$ is earnings before extraordinary items, provisions, and taxes-to-previous period total assets; Capital is the ratio of equity-tototal assets. The vector, $\boldsymbol{V}$, includes Size (natural log of total assets), ROA (return on assets), $B H C$ (unity if a firm is a bank holding company, zero otherwise), S\&L Crisis (unity for 19861992, zero otherwise), GFC (unity for 2007-2010, zero otherwise), GE (unity for years when gubernational elections occur, zero otherwise), $\triangle$ Unemployment and $\triangle G D P$ are annual changes in national unemployment and GDP, respectively.

\section{Results}

Figure 1 shows distributions of ALLP from equation [1] for all banks (Panel A), failed banks (Panel B) and non-failed banks (Panel C). For failed banks, the distribution of abnormal loan loss provisions is platykurtic indicating that failed banks manage accruals more than nonfailed banks.

\footnotetext{
${ }^{3}$ Unrealized gains or losses on available-for-sale securities (AFS) are measured as changes in fair value and reported in the other comprehensive income (OCI) section of equity. On selling AFS, the related amount of holding gains or losses is reclassified into earnings as realized gains or losses. Between 1984 and Q1 2017, changes to accounting standards impacted how firms used AFS in EM (Dong and Zhang, 2018).

${ }^{4}$ LLP is used to adjust the loan loss reserve, a contra-asset reserve and type of regulatory capital that can absorb expected losses. The Basel Accords treat LLR as Tier 2 capital up to $1.25 \%$ of risk-weighted assets. Definitions of regulatory capital can vary across jurisdictions.
} 
We estimate equation [2] for three dependent variables: absolute ALLP (using EM), negative ALLP (income-increasing EM), and positive ALLP (income-decreasing EM). In Table 1, column 1 , the dependent variable is absolute $A L L P$. Its positive and highly significant relationship with Fail shows failing banks use EM to a greater extent than non-failing banks. The coefficients on other covariates indicate the extent of EM is greater when banks report losses, provision more in previous periods, realise larger operational earnings, and are better capitalised. More profitable banks and banks belonging to BHCs appear in less need of EM. The extent of EM is inversely (positively) related to the GFC (S\&L crisis), when elections occur, and when changes in GDP are bigger. Lastly, the extent of EM is unaffected by bank size and unemployment.

While column 1 affirms failed banks' EM behaviour, we cannot deduce the direction of EM; do failed managers pursue upwards management and/or downwards management of earnings? Therefore, we partition the sample by the sign of residuals from equation [1]. If $\varepsilon_{\text {it }}$ $<0, L L P$ is below its predicted value which infers income-increasing, upwards EM achieved by under-provisioning (column 2). If $\varepsilon_{i t}>0, L L P$ exceeds prediction implying income-decreasing, downwards EM due to over-provisioning (column 3).

Column 2 shows a highly significant inverse relationship between the negative residuals of LLP and Fail. It indicates that failed banks aggressively under-provision to upwards manage earnings compared to non-failed under-provisioning banks. This supports views that upwards EM is incentivised by efforts to boost profit and regulatory capital (Beatty and Liao, 2011; Ng and Roychowdhury, 2014) and obfuscation (Beatty et al., 2002; Bergstresser and Philippon, 2006; Imperatore and Trombetta, 2014). Our result is consistent with evidence of banks exploiting EM before and during the GFC: by timing asset write-downs such that they differed from actual losses (Vyas, 2011); by overstating book values of assets by avoiding timely writedowns, delaying LLP, and reclassifying AFS securities as held-to-maturity instruments when fair values dropped below amortised costs (Huizinga and Laeven, 2012).

Column 3 indicates that failed banks set significantly larger provisions than non-failed banks or downwards managed earnings before failing. Whereas over-provisioning suggests capital management by bolstering loan loss reserves, for failed banks aggressive downwards EM infers taking a big bath (Barth et al., 2017) following increased regulatory scrutiny (Rosner, 2003). Downwards EM is consistent with incumbent banks choosing to appear less profitable to deter new entrants and avoid increases in market competitiveness (Tomy, 2019), and to deter takeovers and management buyouts by understating earnings to produce lower firm valuations (De Angelo, 1988).

We repeat our analysis using an alternative indicator of bank failure (see Wheelock and Wilson, 2000). Acquisition equals unity for 2,870 banks acquired without government assistance, zero otherwise. The results from re-estimating equation [2] are consistent with previous in terms of significance though their economic importance is considerably lower (see Table 2).

\section{Conclusion}

Our analysis of EM around bank failures indicates that failing banks engage in EM to a significantly greater extent than non-failing banks. Our results show that failing banks' 
discretion over loan loss provisions ranges from aggressive (upwards EM) to conservative (downwards EM). The results should interest bank regulators and could inform bank supervision to increase monitoring of banks that show an aggressive response to distress. 


\section{References}

Ahmed, A.S., Takeda, C., Thomas, S. (1999). Bank loan loss provisions: A reexamination of capital management, earnings management and signaling effects. Journal of Accounting and Economics, 28(1), 1-25.

Barth, M.E., Gomez-Biscarri, J., Kasznik, R., López-Espinosa, G. (2017). Bank earnings and regulatory capital management using available for sale securities. Review of Accounting Studies, 22(4), 1761-1792.

Barth, M.E., Landsman, W.R., Lang, M.H. (2008). International Accounting Standards and Accounting Quality. Journal of Accounting Research, 46(3), 467-498.

Beatty, A., Ke, B., Petroni, K.R. (2002). Earnings management to avoid earnings declines across publicly and privately held banks. The Accounting Review, 77(3), 547-570.

Beatty, A., Liao, S. (2011). Do Delays in Expected Loss Recognition Affect Banks' Willingness to Lend? Journal of Accounting and Economics, 52, 1-20.

Beatty, A., Liao, S. (2014). Financial accounting in the banking industry: A review of the empirical literature. Journal of Accounting and Economics, 58(2-3), 339-383.

Bennett, R.L., Unal, H. (2010). The cost effectiveness of the private-sector resolution of failed bank assets, FDIC Center for Financial Research, Working paper, No. 2009-11. Bergstresser, D., Philippon, T. (2006). Manager Incentives and Earnings Management. Journal of Financial Economics, 80(3), 511-529.

Blix Grimaldi, M., Hofmeister, J., Schich, S., Snethlage, D. (2016) Estimating the size and incidence of bank resolution costs for selected banks in OECD countries. OECD Journal: Financial Market Trends, 2016/1, https://doi.org/10.1787/fmt-2016-5jlvbslktw7j.

Brunnermeier, M.K. (2009). Deciphering the Liquidity and Credit Crunch 2007-2008. Journal of Economic Perspectives, 23(1), 77-100.

Bushman, R.M. (2014). Thoughts on financial accounting and the banking industry. Journal of Accounting and Economics, 58(2-3), 384-395.

Calomiris, C., Gorton, G., 1991. The origins of banking panics. Financial Markets and Financial Crisis. University of Chicago Press, Chicago109-172.

Cohen, L.J., Cornett, M.M., Marcus, A.J., Tehranian, H. (2014). Bank earnings management and tail risk during the financial crisis. Journal of Money, Credit, and Banking, 46(1) 171-197. Cornett, M.M., McNutt, J.J. Tehranian, H. (2009). Corporate governance and earnings management at large US bank holding companies, Journal of Corporate Finance, 15(4), 412430.

DeAngelo, L. (1988). Discussion of: Evidence of earnings management from the provision for bad debts, Journal of Accounting Research, 26(Suppl), 32-40.

Dewally, M., Shao, Y. (2013). Financial derivatives, opacity, and crash risk: Evidence from large US banks, Journal of Financial Stability, 9(4), 565-577

Dong, M., Zhang, X.J. (2018) Selective Trading of Available-for-Sale Securities: Evidence from U.S. Commercial Banks. European Accounting Review, 27(3), 1-27.

Holmstrom, B., 2009. Commentary: The Panic of 2007, 〈http://www.kc.frb.org/publicat/sympos/2008/Holmstrom.03.12.09.pdf).

Holod, D., Peek, J., 2007. Asymmetric information and liquidity constraints: a new test. Journal of Banking \& Finance 31, 2425-2451.

Huizinga, H., Laeven, L. (2012). Bank valuation and accounting discretion during a financial crisis. Journal of Financial Economics, 106, 614-634.

James, C. (1991). The Losses Realized in Bank Failures. The Journal of Finance, 46(4), $1223-$ 1242. 
Jiang, L., Levine, R., Lin, C. (2016). Competition and bank opacity. Review of Financial Studies, 29(7), 1911-1942.

Kaplan, S.E., Ravenscroft, S.P. (2004). The reputation effects of earnings management in the internal labor market, Business Ethics Quarterly, 14(3), 453-478.

Laeven, L., Majnoni, G. (2003). Loan loss provisioning and economic slowdowns: too much, too late? Journal of Financial Intermediation, 12(2), 178-197.

$\mathrm{Ng}$, J., Roychowdhury, S. (2014). Do Loan Loss Reserves Behave Like Capital? Evidence from Recent Bank Failures, Review of Accounting Studies, 19, 1234-1279.

Norden, L., Stoian, A. (2014) Bank earnings management through loan loss provisions: A double-edged sword? De Nederlandsche Bank Working Paper No. 404.

Rosner, R.L. (2003). Earnings manipulation in failing firms, Contemporary Accounting Research, 20(2), 361-408.

Schoen, E.J. (2017). The 2007-2009 Financial Crisis: An Erosion of Ethics: A Case Study. Journal of Business Ethics, 146(4), 805-830.

Tomy, R.E. (2019). Threat of entry and the use of discretion in banks' financial reporting, Journal of Accounting and Economics, 67(1), 1-35.

Trombetta, M., Imperatore, C. (2014). The dynamic of financial crises and its non-monotonic effects on earnings quality, Journal of Accounting and Public Policy, 33(3), 205-232.

Vyas, D. (2011). The timeliness of accounting write-downs by U.S. financial institutions during the financial crisis of 2007-2008, Journal of Accounting Research, 49(3), 823-860. Wagner, W. (2007). Financial development and the opacity of banks, Economic Letters, 97, 6-10.

Wheelock, D.C., Wilson, P.W. (2000). Why do banks disappear? The determinants of U.S. bank failures and acquisitions, Review of Economics and Statistics, 82(1), 127-138. 


\begin{tabular}{|c|c|c|c|}
\hline VARIABLES & $\begin{array}{c}1) \\
\text { Absolute } \\
\text { Residuals }\end{array}$ & $\begin{array}{c}\text { (2) } \\
\text { Negative } \\
\text { Residuals }\end{array}$ & $\begin{array}{c}\text { (3) } \\
\text { Positive Residuals }\end{array}$ \\
\hline Fail & $\begin{array}{l}0.181 * * * \\
(10.884)\end{array}$ & $\begin{array}{c}-0.165^{* * *} \\
(-6.700)\end{array}$ & $\begin{array}{c}0.182^{* * *} \\
(8.428)\end{array}$ \\
\hline Loss & $\begin{array}{c}0.255^{* * *} \\
(65.143)\end{array}$ & $\begin{array}{r}-0.093 * * * \\
(-22.094)\end{array}$ & $\begin{array}{c}0.376 * * * \\
(63.458)\end{array}$ \\
\hline $\operatorname{LLP}_{t-1}$ & $\begin{array}{c}0.079 * * * \\
(35.671)\end{array}$ & $\begin{array}{c}-0.077^{* * *} \\
(-27.500)\end{array}$ & $\begin{array}{c}0.077^{* * *} \\
(25.801)\end{array}$ \\
\hline EBELT & $\begin{array}{c}0.032 * * * \\
(23.639)\end{array}$ & $\begin{array}{l}-0.027 * * * \\
(-17.138)\end{array}$ & $\begin{array}{l}0.038 * * * \\
(16.893)\end{array}$ \\
\hline Capital $\left.\right|_{-1}$ & $\begin{array}{c}0.002^{* * *} \\
(5.983)\end{array}$ & $\begin{array}{c}-0.000 \\
(-0.371)\end{array}$ & $\begin{array}{c}0.004^{* * *} \\
(8.954)\end{array}$ \\
\hline Size & $\begin{array}{c}-0.001 \\
(-1.204)\end{array}$ & $\begin{array}{c}-0.002 * * * \\
(-3.609)\end{array}$ & $\begin{array}{c}-0.006 * * * \\
(-7.142)\end{array}$ \\
\hline $\mathrm{ROA}_{t-1}$ & $\begin{array}{c}-0.019 * * * \\
(-11.576)\end{array}$ & $\begin{array}{c}0.040 * * * \\
(20.694)\end{array}$ & $\begin{array}{c}0.001 \\
(0.570)\end{array}$ \\
\hline $\mathrm{BHC}$ & $\begin{array}{c}-0.006^{* * *} \\
(-3.755)\end{array}$ & $\begin{array}{c}0.001 \\
(0.337)\end{array}$ & $\begin{array}{c}-0.011 * * * \\
(-4.680)\end{array}$ \\
\hline S\&L Crisis & $\begin{array}{c}0.042 * * * \\
(6.280)\end{array}$ & $\begin{array}{c}-0.047 * * * \\
(-5.406)\end{array}$ & $\begin{array}{c}0.037^{* * *} \\
(3.424)\end{array}$ \\
\hline GFC & $\begin{array}{c}-0.089 * * \\
(-2.067)\end{array}$ & $\begin{array}{l}0.114^{*} \\
(1.676)\end{array}$ & $\begin{array}{c}-0.081 \\
(-1.327)\end{array}$ \\
\hline Gubernatorial Elections & $\begin{array}{c}-0.004 * * * \\
(-3.528)\end{array}$ & $\begin{array}{c}0.002 \\
(1.625)\end{array}$ & $\begin{array}{c}-0.006 * * * \\
(-3.454)\end{array}$ \\
\hline US Unemployment $t_{t-1}$ & $\begin{array}{c}0.023 \\
(0.418)\end{array}$ & $\begin{array}{c}-0.023 \\
(-0.272)\end{array}$ & $\begin{array}{c}0.014 \\
(0.173)\end{array}$ \\
\hline$\Delta \mathrm{GDP}_{t-1}$ & $\begin{array}{c}-0.015^{* * *} \\
(-3.758)\end{array}$ & $\begin{array}{c}0.019 * * * \\
(3.121)\end{array}$ & $\begin{array}{c}-0.015^{* * *} \\
(-2.577)\end{array}$ \\
\hline Constant & $\begin{array}{c}0.079 * * * \\
(35.671)\end{array}$ & $\begin{array}{r}-0.077^{* * *} \\
(-27.500)\end{array}$ & $\begin{array}{c}0.077^{* * * *} \\
(25.801)\end{array}$ \\
\hline Observations & 257,881 & 146,678 & 111,203 \\
\hline R-squared & 0.222 & 0.187 & 0.277 \\
\hline Year Controls & YES & YES & YES \\
\hline
\end{tabular}

Note: ${ }^{* * *}$ and ${ }^{* *}$ indicate significance at the 1 and 5 percent levels. 


\begin{tabular}{|c|c|c|c|}
\hline VARIABLES & $\begin{array}{c}(1) \\
\text { Absolute } \\
\text { Residuals }\end{array}$ & $\begin{array}{c}\text { (2) } \\
\text { Negative } \\
\text { Residuals }\end{array}$ & $\begin{array}{c}\text { (3) } \\
\text { Positive Residuals }\end{array}$ \\
\hline Acquisition & $\begin{array}{c}0.015^{* * *} \\
(3.185)\end{array}$ & $\begin{array}{c}-0.011^{* *} \\
(-2.131)\end{array}$ & $\begin{array}{c}0.022 * * * \\
(2.752)\end{array}$ \\
\hline Loss & $\begin{array}{c}0.261 * * * \\
(66.828)\end{array}$ & $\begin{array}{c}-0.098 * * * \\
(-23.354)\end{array}$ & $\begin{array}{c}0.382 * * * \\
(64.580)\end{array}$ \\
\hline $\operatorname{LLP}_{t-1}$ & $\begin{array}{c}0.081^{* * *} \\
(37.116)\end{array}$ & $\begin{array}{c}-0.078 * * * \\
(-27.935)\end{array}$ & $\begin{array}{c}0.081^{* * *} \\
(27.290)\end{array}$ \\
\hline EBELT & $\begin{array}{c}0.031 * * * \\
(22.845)\end{array}$ & $\begin{array}{c}-0.027^{* * *} \\
(-16.913)\end{array}$ & $\begin{array}{c}0.036 * * * \\
(16.028)\end{array}$ \\
\hline Capital $_{t-1}$ & $\begin{array}{c}0.002^{* * *} \\
(5.485)\end{array}$ & $\begin{array}{c}-0.000 \\
(-0.022)\end{array}$ & $\begin{array}{c}0.004^{* * *} \\
(8.441)\end{array}$ \\
\hline Size & $\begin{array}{l}-0.001 \\
(-1.085)\end{array}$ & $\begin{array}{c}-0.002 * * * \\
(-3.550)\end{array}$ & $\begin{array}{c}-0.006 * * * \\
(-6.964)\end{array}$ \\
\hline $\mathrm{ROA}_{t-1}$ & $\begin{array}{c}-0.019 * * * \\
(-11.632)\end{array}$ & $\begin{array}{c}0.041 * * * \\
(20.884)\end{array}$ & $\begin{array}{c}0.002 \\
(0.650)\end{array}$ \\
\hline $\mathrm{BHC}$ & $\begin{array}{c}-0.006 * * * \\
(-3.911)\end{array}$ & $\begin{array}{c}0.001 \\
(0.470)\end{array}$ & $\begin{array}{c}-0.011 * * * \\
(-4.814)\end{array}$ \\
\hline S\&L Crisis & $\begin{array}{c}0.043 * * * \\
(6.446)\end{array}$ & $\begin{array}{c}-0.047 * * * \\
(-5.425)\end{array}$ & $\begin{array}{c}0.040 * * * \\
(3.613)\end{array}$ \\
\hline GFC & $\begin{array}{l}-0.105^{* *} \\
(-2.433)\end{array}$ & $\begin{array}{l}0.122^{*} \\
(1.791)\end{array}$ & $\begin{array}{l}-0.108^{*} \\
(-1.760)\end{array}$ \\
\hline Gubernatorial Elections & $\begin{array}{c}-0.005^{* * *} \\
(-4.426)\end{array}$ & $\begin{array}{l}0.002^{* *} \\
(1.961)\end{array}$ & $\begin{array}{c}-0.008^{* * *} \\
(-4.286)\end{array}$ \\
\hline US Unemployment $t_{t-1}$ & $\begin{array}{c}0.042 \\
(0.758)\end{array}$ & $\begin{array}{l}-0.034 \\
(-0.400)\end{array}$ & $\begin{array}{c}0.044 \\
(0.548)\end{array}$ \\
\hline$\Delta \mathrm{GDP}_{t-1}$ & $\begin{array}{c}-0.016 * * * \\
(-4.078)\end{array}$ & $\begin{array}{c}0.020^{* * *} \\
(3.206)\end{array}$ & $\begin{array}{c}-0.017 * * * \\
(-2.963)\end{array}$ \\
\hline Constant & $\begin{array}{c}0.081^{* * *} \\
(37.116)\end{array}$ & $\begin{array}{c}-0.078 * * * \\
(-27.935)\end{array}$ & $\begin{array}{c}0.081^{* * *} \\
(27.290)\end{array}$ \\
\hline Observations & 257,881 & 146,678 & 111,203 \\
\hline R-squared & 0.219 & 0.185 & 0.274 \\
\hline Year Controls & YES & YES & YES \\
\hline
\end{tabular}

Note: $^{* * *}$ and ${ }^{* *}$ indicate significance at the 1 and 5 percent levels. 
Figure 1: Distributions of ALLP Obtained from Equation [1]
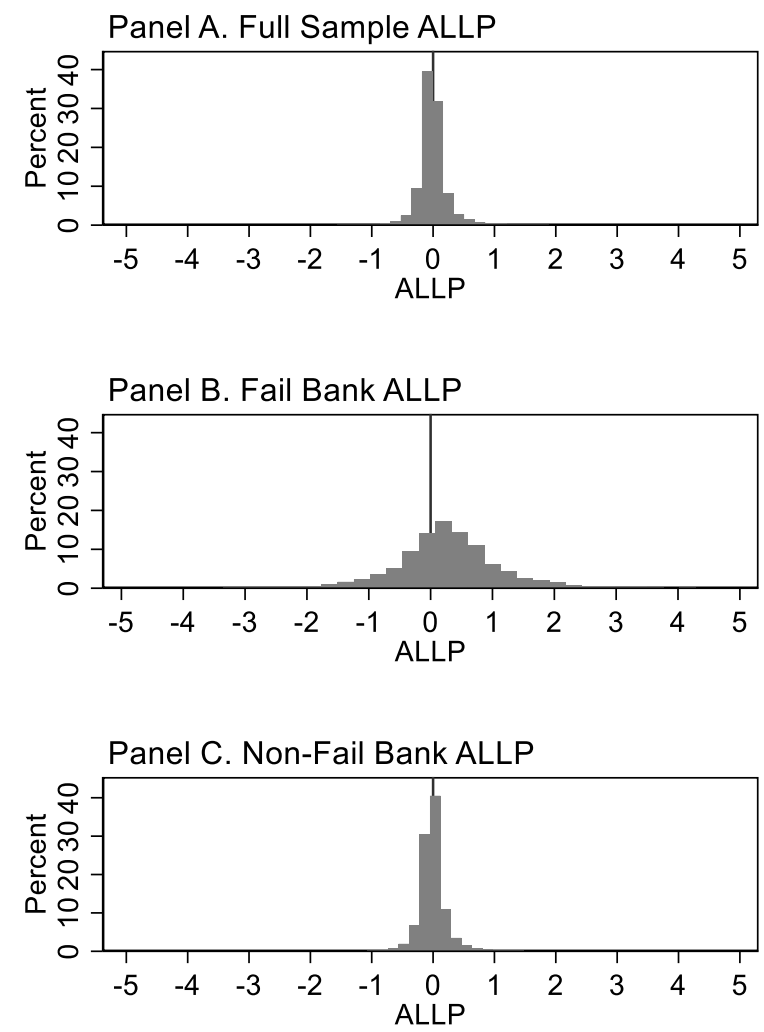